\title{
Teaching Strategies: How A Modular Integrated System Can Become A Real Success in Medical Schools?
}

\author{
Muhammad Abdul Azeem* \\ Professor of Physiology, United Medical and Dental College, Karachi, Pakistan
}

Submission: October 03, 2017; Published: October 17, 2017

*Corresponding author: Muhammad Abdul Azeem, Professor of Physiology, United Medical and Dental College, Karachi, Pakistan; Email: azenmu@gmail.com

\section{Mini Review}

In modular teaching, spirals involve both the horizontal and vertical integration by uniting them across time and across disciplines Brauer and Ferguson [1]; Bandiera et al. [2] described it, in terms of curriculum, involving learning of basic and clinical sciences across both time and subject matter. Such modular teachings expose the students for professional thinking right from the beginning of their academics. While in conventional teaching, the student remains professionally away from clinical aspects during first two years of schooling. Although, there is no doubt about the validity and reliability of modular teaching but, this teaching system is yet not equivocally advocated for the best outcomes in different institutions. The critics are more vocal for a sound basic knowledge of Anatomy, Physiology \& Biochemistry in the first two years instead of amalgamation with the Pharmacology, Pathology and Community Medicine or pure clinical ones. The bases for this un-equivocality to advocate modular integrated teaching is actually based on some odds in the planning $\&$ execution of this system. These are:

a) Un-organized and enormous teaching of Pharmacology, Pathology and clinical subjects at the expense of Anatomy, Physiology \& Biochemistry.

b) Shortcomings in pre-schooling render the students to take more time for the understanding to integrate Anatomy, Physiology and Biochemistry with the Pharmacology, Pathology and Community Medicine as well as behavioral sciences. They are also not well adjusted for problem based/case based learning.

c) A huge burden of Pathology \& Pharmacology in first two years is difficult to understand and thus even good students get just passing marks in some of the continuous assessment tests, which are not spaced appropriately between the end of one module and the start of next one.

d) Non-availability of funds restricts laboratory experiments by replacing them with simulation/demonstrations only, instead of performance. Consequently, understanding of basic mechanisms suffers at both the cellular or systemic levels leading to deficiencies in the understanding of disease mechanism.

e) Unawareness of the faculty to handle the modular integrated system of teaching in its true spirit.

f) Unsuccessful integration among contents of a lecture and across the subjects.

Recently, the Australian Medical Council included the traditional domain along with the domains of science-scholarship and clinical-practice by relating them with the domains of health-society and professionalism-leadership AMC [3]. This Australian strategy that advocate starting with the traditional domains can remove the criticism on modular integrated system, based upon reduction in the input from basic science subjects of Anatomy, Physiology and Biochemistry.

In order to get the desired outcomes from the modular integrated teaching strategy a thorough planning is needed that should consider the following especially by the institutions that are not getting the desired outcomes from such teaching strategy:

a. Appropriate modular contents with integration within a subject and across subjects.

b. Excellent mapping Edmondson [4] for both the vertical and horizontal integration with a comprehensive teaching \& exam time table.

c. Comprehensive merit admission policy to recruit students of roughly uniform caliber.

d. Training to the faculty to impart modular integrated teaching Cooke et al. [5].

\section{References}

1. David G Brauer, Kristi J Ferguson (2015) The integrated curriculum in medical education AMEE Guide \# 96: Washington University School of Medicine, USA, University of Iowa, USA. Medical Teacher 37: 312-322. 
2. Bandiera G, Boucher A, Neville A, Kuper A, Hodges B (2013) Integration and timing of basic and clinical sciences education. Med Teach 35(5): 381-387.

3. Annual Report (Australian Medical Council 2012).
4. Edmondson KM (1995) Concept mapping for the development of medicalcurricula. J Res Sci Teach 32(7): 777-793.

5. Cooke M, Irby DM, Sullivan W, Ludmerer KM (2006) American medical education 100 years after the Flexner report. N Engl J Med 355(13): 1339-1344.

\section{Your next submission with Juniper Publishers will reach you the below assets}

- Quality Editorial service

- Swift Peer Review

- Reprints availability

- E-prints Service

- Manuscript Podcast for convenient understanding

- Global attainment for your research

- Manuscript accessibility in different formats (Pdf, E-pub, Full Text, Audio)

- Unceasing customer service

Track the below URL for one-step submission https://juniperpublishers.com/online-submission.php 